\title{
Investigation of Thin Film Solar Cells on CdS/CdTe Base with Different Back Contacts
}

\author{
G. Khrypunov ${ }^{1}$, A. Meriuts ${ }^{1}$, H. Klochko ${ }^{1}$, T. Shelest ${ }^{1}$, A. Khrypunova ${ }^{2}$ \\ ${ }^{1}$ National Technical University «Kharkiv Polytechnical Institute», \\ 21, Frunze Str., 61002, Kharkiv, Ukraine \\ ${ }^{2}$ University of Ukraine Civil Defense \\ 94, Chernushevskogo Str., 61023, Kharkiv, Ukraine
}

Keywords: Solar cell, thin film, CdTe, back contact

\begin{abstract}
.
The peculiarities of photo-electric processes in thin film CdS/CdTe solar cells (SC) with different back electrodes $(\mathrm{Cu} / \mathrm{Au}, \mathrm{ITO}, \mathrm{Cu} / \mathrm{ITO})$ have been studied. As it was established by capacitance - voltage $(\mathrm{C}-\mathrm{V})$ characteristics, the potential barrier heights for $\mathrm{CdTe} / \mathrm{Cu} / \mathrm{Au}$ and $\mathrm{CdTe} / \mathrm{ITO}$ were $0.3 \mathrm{eV}$ and $2.2 \mathrm{eV}$, respectively. The concentrations of charge carriers near back contact consisted $9 \cdot 10^{20} \mathrm{~m}^{-3}$ and $2 \cdot 10^{21} \mathrm{~m}^{-3}$, respectively. A high carrier concentration and high potential barrier of the ITO back contact caused the tunnel - recombination mechanism of the charge transport. The investigations of $\mathrm{CdS} / \mathrm{CdTe} / \mathrm{ITO}$ SC spectral photosensitivity testify a negative impact of the developed grain-boundary surface of the base layer on the processes of diffusion and separation of non-equilibrium current carriers generated by short-wave radiation. It is shown that the deposition of $\mathrm{Cu}$ nanolayer before the deposition of ITO films give stable efficiency $10 \%$ for bifacial CdS/CdTe solar cells.
\end{abstract}

\section{Introduction}

$\mathrm{CdTe} / \mathrm{CdS}$ thin film solar cells are perspective for large-scale terrestrial application. Two interest lines of terrestrial device development are the creation of bifacial CdS/CdTe solar cells supplied with transparent front and back electrodes and a tandem device structure based on two absorbers with different band gap, that ensures photovoltaic conversion in wide spectral range as such as design of the top more wide band gap base layer allows transmittance of long-wave part of sun light to the back absorber with narrower band gap. Recently; a new construction of the CdS/CdTe SC with transparent indium-tin oxide (ITO) film back electrode has been proposed for the tandem SC. With this purpose we carried out comparative investigation of solar cells

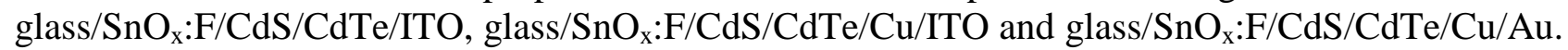
In this work the peculiarities of photo-electric processes in CdS/CdTe SC with transparent back film electrodes have been studied.

\section{Experimental}

The CdS/CdTe/ITO film heterosystems were prepared by thermal vacuum evaporation on glass substrates covered with $\mathrm{SnO}_{\mathrm{x}}: \mathrm{F}$. "Chloride" treatment was applied by $\mathrm{CdCl}_{2}$ evaporation onto CdTe surface and by following air-annealing of the stack at $430^{\circ} \mathrm{C}$. Prior to the formation of back electrode, the surface of the CdTe base layer was etched in a bromine-methanol solution. Next 300 - $350 \mathrm{~nm}$ thick ITO layer was deposited onto the etched surface by nonreactive high-frequency magnetron sputtering at $250^{\circ} \mathrm{C}$. For the purpose of development of the back electrode for the glass $/ \mathrm{SnO}_{\mathrm{x}}: \mathrm{F} / \mathrm{CdS} / \mathrm{CdTe} / \mathrm{Cu} / \mathrm{Au}$ solar cell, $\mathrm{Cu} 11 \mathrm{~nm}$ thick films and $\mathrm{Au} 50 \mathrm{~nm}$ thick films were sequentially deposited onto the etched base layer surface by thermal vacuum evaporation. Then the solar cells were air-annealed at $250^{\circ} \mathrm{C}$ for $25 \mathrm{~min}$. To form the back electrode for the glass $/ \mathrm{SnO}_{\mathrm{x}}: \mathrm{F} / \mathrm{CdS} / \mathrm{CdTe} / \mathrm{Cu} / \mathrm{ITO}$ solar cell the less thin then $1 \mathrm{~nm}$ thick $\mathrm{Cu}$ film was deposited by 
thermal vacuum evaporation on the surface of the etched base layer, whereupon 300-350 nm thick ITO layer was deposited by nonreactive high-frequency magnetron sputtering at $250^{\circ} \mathrm{C}$.

The current - voltage (I-V) characteristics were measured using an automated 4145A Semiconductor Analyzer (Hewlett Packard). To measure the I-V characteristics of the solar cells at various temperatures, the samples were placed in a temperature-controlled box. The temperature was measured accurate within $\pm 1^{\circ} \mathrm{C}$ using a Peltier cell (PRG H100 control unit, Peltron GmbH). To exclude the effect of water vapor condensation on the solar cell surface on the results of the measurements, a constant nitrogen flow was passed through the box. The capacitance - voltage (CV) characteristics were measured using a high frequency HP4275A Hewlett Packard LCR-meter; during the measurements a constant voltage in the range from $-2 \mathrm{~V}$ to $+2 \mathrm{~V}$ and a sinusoidal signal with the frequency $100 \mathrm{kHz}$ and amplitude $10 \mathrm{mV}$ were fed simultaneously to the sample. According to the published data [1], the shape of the $\mathrm{C}-\mathrm{V}$ characteristics of the $\mathrm{CdS} / \mathrm{CdTe}$ based thin film solar cells at this frequency is mainly determined by the variations in the sizes of the space charge regions.

For calculation of coefficient of quantum efficiency $Q(\lambda)$ the measurements of density of a short-circuit current $J_{\mathrm{sh}}(\lambda)$ were carried out. We used an optoelectronic system consisted of a halogen tube with power and cooling units, a pulse light modulator, a monochromator and a detector block for measuring the amplitude and polarity of photocurrent pulses generated by a heterosystem when being illuminated by a pulse signal. The photocurrent polarity in the $\mathrm{CdS} / \mathrm{CdTe} / \mathrm{Cu} / \mathrm{Au}$ heterosystem was adopted as positive, the opposite one as negative. The optoelectronic system provided an opportunity to apply a constant voltage $U$ across a researched heterosystem in the course of measurements. The $230-\mathrm{Hz}$ modulation of a light flux was used to avoid the influence of external light sources and the constant voltage applied to the structure on the measured values of $J_{\mathrm{sh}}(\lambda)$. It allowed the constant component of the photocurrent to be compensated automatically during measurements. The measuring procedures and the processing of data were carried out with the help of a PC. For a comparative analysis of glass $/ \mathrm{SnO}_{\mathrm{x}}: \mathrm{F} / \mathrm{CdS} / \mathrm{CdTe} / \mathrm{ITO}$ and glass $/ \mathrm{SnO}_{\mathrm{x}}: \mathrm{F} / \mathrm{CdS} / \mathrm{CdTe} / \mathrm{Cu} / \mathrm{Au} \mathrm{SC}$, the absolute values of $Q(\lambda)$ were normalized by the maximal value of the quantum efficiency coefficient measured for the glass $/ \mathrm{SnO}_{\mathrm{x}}: \mathrm{F} / \mathrm{CdS} / \mathrm{CdTe} / \mathrm{Cu} / \mathrm{Au} \mathrm{SC}$ at $U=0$.

\section{Results and discussion}

The analyses of the $\mathrm{I}-\mathrm{V}$ characteristics of the studied glass $/ \mathrm{SnO}$ : $: \mathrm{F} / \mathrm{CdS} / \mathrm{CdTe} / \mathrm{Cu} / \mathrm{Au}$ solar cells under the forward bias show a plateau at $U>1 \mathrm{~V}$. The current density, which corresponds to the plateau, increases as the temperature increases. Consequently, the density of the current flowing across the solar cell starts to be limited by the density of the saturation current of the back contact $J_{\mathrm{sb}}$. The exponential dependence of $J_{\mathrm{sb}}(T)$ on $1 / T$ indicates the thermal emission mechanism of the charge transport that exists in the device structure in the mentioned voltage range:

$$
J_{\mathrm{sb}}=J_{\mathrm{sb} 0} \exp \left(-E_{\mathrm{ab}} / k T\right) \text {. }
$$

Here $E_{\mathrm{ab}}$ is the activation energy of the saturation current of the back contact.

This quantity is related to the potential-barrier height $\mathrm{E}_{\mathrm{bb}}$ of the back contact by the relation $E_{\mathrm{ab}}=E_{\mathrm{bb}} / A$. For the sample which was studied, $E_{\mathrm{ab}}=0.16 \mathrm{eV}$ and coefficient ideality $A=1.9$. Consequently, $E_{\mathrm{bb}}=0.30 \mathrm{eV}$. The obtained value of the potential-barrier height virtually coincides with the value $E_{b b}=(0.31-0.33) \mathrm{eV}$, which was obtained for such solar cells using a similar method [2]. In the $I-V$ characteristics of the $\mathrm{CdS} / \mathrm{CdTe} / \mathrm{ITO}$ structures, no temperature dependence of the saturation current was observed under the forward bias $U>1 \mathrm{~V}$. For such bias-voltage values, the current $J$ depends exponentially on $U^{-1 / 2}$. Sharma and Purohit [3] believe that this fact is 
indicative of the existence of the tunnel-recombination mechanism of the charge transport in the device structure, for which the expression for current density is written as:

$$
J \sim \exp \left\{-B\left(U_{\mathrm{bb}}-U\right)^{-1 / 2}\right\}
$$

Here $B$ is a parameter determined by the physical characteristics of the $n$-type material and $\mathrm{U}_{\mathrm{bb}}$ is the contact potential difference $\left(E_{\mathrm{bb}}=e U_{\mathrm{bb}}\right)$.

The capacitance-voltage characteristics for glass/SnO $: \mathrm{F} / \mathrm{CdS} / \mathrm{CdTe} / \mathrm{Cu} / \mathrm{Au}$ and glass $/ \mathrm{SnO}_{\mathrm{x}}: \mathrm{F} / \mathrm{CdS} / \mathrm{CdTe} / \mathrm{ITO}$ solar cells include several typical portions. The first portion corresponds to the reverse bias and a low forward bias $(U \leq 0.2-0.3 \mathrm{~V})$. In this portion, the $\mathrm{C}-\mathrm{V}$ characteristics are linearized in the coordinates $S^{2} / C^{2}=f(U)$. Niemegeers and Burgelman [4] believe that, for this portion, the current density across the glass $/ \mathrm{SnO}_{\mathrm{x}}: \mathrm{F} / \mathrm{CdS} / \mathrm{CdTe} / \mathrm{Cu} / \mathrm{Au}$ solar cell is much lower that the saturation current density of the back contact $J_{\mathrm{sb}}$. Therefore, the applied voltage drops completely across the $p-n$ junction. Consequently, the total capacitance of the solar cell for this portion corresponds to the capacitance of the $p-n$ junction. It was experimentally found that the second characteristic portion in the dependences $S^{2} / C^{2}=f(U)$ for the studied device structures (where $\mathrm{S}$ is the area of the deposition layer) exists under the positive bias $U>1 \mathrm{~V}$ for the $\mathrm{CdS} / \mathrm{CdTe} / \mathrm{Cu} / \mathrm{Au}$ structures and $U>0.8 \mathrm{~V}$ for the $\mathrm{CdS} / \mathrm{CdTe} / \mathrm{ITO}$ structures. In this range of the applied voltages, the $\mathrm{C}-\mathrm{V}$ characteristics for both types of solar cells are also linearized if represented as $S^{2} / C^{2}=f(U)$. It was shown that, in this portion, the applied voltage drops mainly across the back rectifying contact, which is reverse-biased in this case, and the total capacitance of the solar cell is determined by the contact capacitance [4]. Under such forward biases, the sizes of the depletion region of the $p-n$ junction and, correspondingly, the resistance of the depletion region decrease. The height of the potential barrier, which emerges during formation of the back contact to the base CdTe layer, and the carrier concentration near the back contact $\left(N_{\mathrm{b}}\right)$ were determined from the linear portion of the dependence $S^{2} / C^{2}=f(U)$, similarly to study [5]. For the CdS/CdTe/Cu/Au structures, $E_{\mathrm{bb}}=0.25 \mathrm{eV}$, which corresponds to the value of this parameter found by us from the analysis of the dark I-V characteristic. For the CdS/CdTe/ITO structures, $E_{\mathrm{bb}}=2.2 \mathrm{eV}$. In this case, concentration of charge carriers is $N_{\mathrm{b}}=9.5 \cdot 10^{20} \mathrm{~m}^{-3}$ for the $\mathrm{CdS} / \mathrm{CdTe} / \mathrm{Cu} / \mathrm{Au}$ structures, and $N_{\mathrm{b}}=2 \cdot 10^{21} \mathrm{~m}^{-3}$ for the CdS/CdTe/ITO structures. A high carrier concentration near the back contact and a high potential barrier of the back contact gave rise to the tunnel-recombination mechanism of the charge transport in the glass/SnO $: \mathrm{F} / \mathrm{CdS} / \mathrm{CdTe} / \mathrm{ITO}$ solar cells under the forward-bias voltage above $1 \mathrm{~V}$, which follows from the analysis of the dark I-V characteristics.

Comparative studies of the coefficient of quantum efficiency $Q(\lambda)$ dependences, obtained for glass $/ \mathrm{SnO}_{\mathrm{x}}: \mathrm{F} / \mathrm{CdS} / \mathrm{CdTe} / \mathrm{Cu} / \mathrm{Au}$ and glass $/ \mathrm{SnO} \mathrm{x}_{\mathrm{x}}: \mathrm{F} / \mathrm{CdS} / \mathrm{CdTe} / \mathrm{ITO}$ solar cells were carried out. Provided that the glass $/ \mathrm{SnO}_{\mathrm{x}}: \mathrm{F} / \mathrm{CdS} / \mathrm{CdTe} / \mathrm{Cu} / \mathrm{Au} \mathrm{SC}$ was illuminated from the frontal side (from the side of the glass substrate) and no electric bias was applied, the corresponding $Q(\lambda)$ dependence, in comparison with that of the glass $/ \mathrm{SnO}_{\mathrm{x}}: \mathrm{F} / \mathrm{CdS} / \mathrm{CdTe} / \mathrm{ITO} \mathrm{SC}$, had higher values in the whole spectral range of photosensitivity (Fig. 1, curves 1,2). The largest difference between the corresponding $Q(\lambda)$-values of the investigated heterosystems amounted to 0.4 at the wavelength $\lambda=550 \mathrm{~nm}$ (Fig. 1, curve 3).

According to the energy structure of cadmium sulfide, the edge of the absorption band of this substance is situated at $520-540 \mathrm{~nm}$, so that, when the studied heterosystems were illuminated from the CdS side, $550 \mathrm{~nm}$ photons had the highest energy among those photons that were not absorbed substantially in the cadmium sulfide layer and reached the base layer of cadmium telluride. In this case, in accordance with the energy of photons, the range of their absorption was located near the CdS/CdTe interface. Thus, the revealed difference between the corresponding $Q(\lambda)$ values of the investigated heterosystems testifies to that recombination losses near CdS/CdTe 


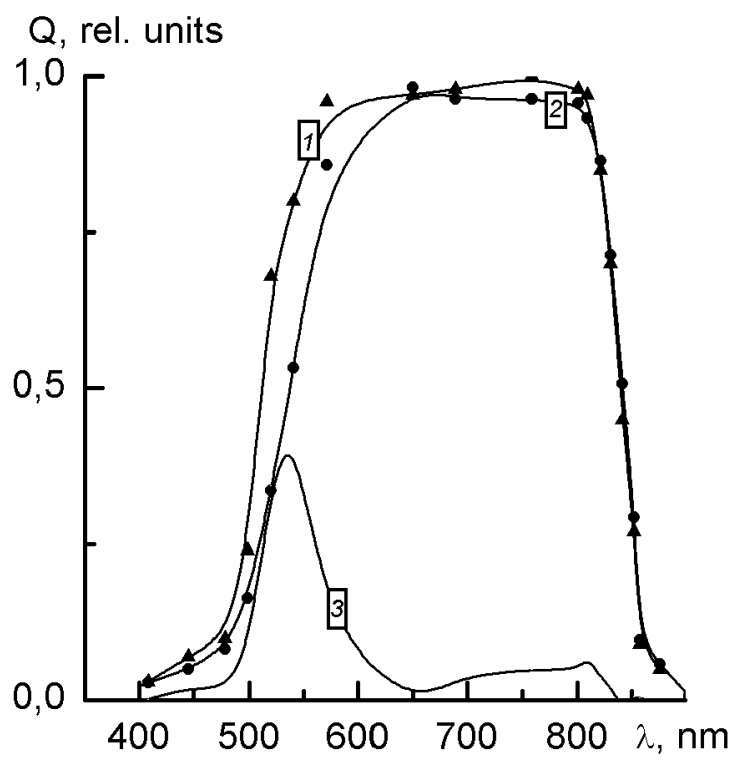

Fig. 1. The coefficient of quantum efficiency $Q(\lambda)$ at $U=0$. SC $\mathrm{CdS} / \mathrm{CdTe} / \mathrm{Cu} / \mathrm{Au}$ (curve 1) and CS CdS/CdTe/ITO (curve 2); difference of quantum efficiency $Q_{\mathrm{Cu} / \mathrm{Au}}-Q_{\mathrm{ITO}}$ (curve 3 ).

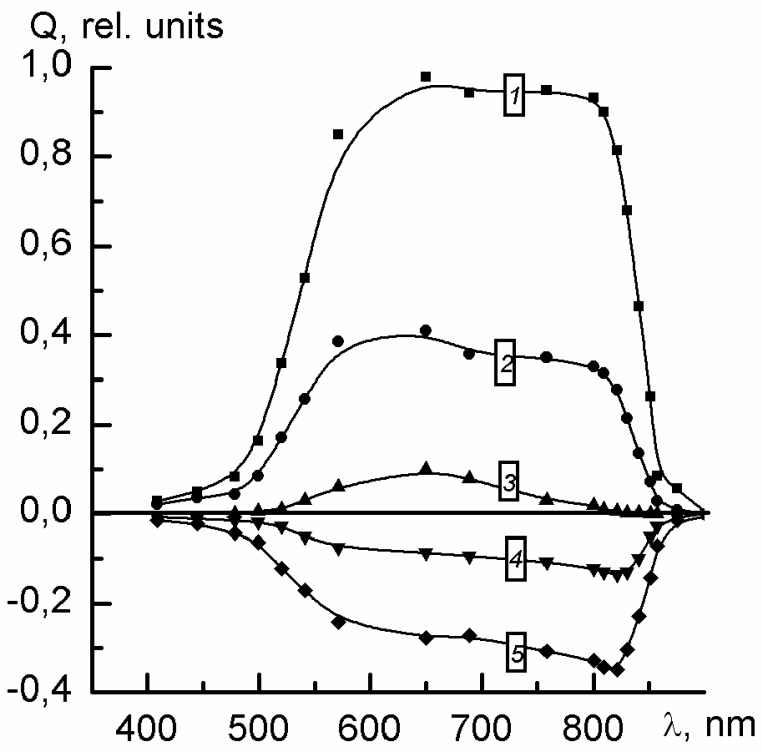

Fig. 2. The coefficient of quantum efficiency $Q(\lambda) \mathrm{SC} \mathrm{CdS/CdTe/ITO} \mathrm{at} \mathrm{the} \mathrm{front} \mathrm{illumination}$ and different voltage: $U=0$ (curve 1 ), $0.6 \mathrm{~V}$ (curve 2), $0.7 \mathrm{~V}$ (curve 3), $0.8 \mathrm{~V}$ (curve 4) and $1.2 \mathrm{~V}$ (curve 5).

interface of the glass $/ \mathrm{SnO}_{\mathrm{x}}: \mathrm{F} / \mathrm{CdS} / \mathrm{CdTe} / \mathrm{Cu} / \mathrm{Au} \quad \mathrm{SC}$ were lower than those in the glass $/ \mathrm{SnO}_{\mathrm{x}}: \mathrm{F} / \mathrm{CdS} / \mathrm{CdTe} / \mathrm{Cu} / \mathrm{Au} \mathrm{SC}$ itself. The authors of work [6] believe that copper atoms, diffusing over the grain boundaries, can passivate the grain- boundary surface near $\mathrm{CdS} / \mathrm{CdTe}$ interface in the course of the formation of back $\mathrm{Au} / \mathrm{Cu}$ contacts. This reduces the rate of recombination in this layer and results in an increase of $Q(\lambda)$ for the glass $/ \mathrm{SnO}_{\mathrm{x}}: \mathrm{F} / \mathrm{CdS} / \mathrm{CdTe} / \mathrm{Cu} / \mathrm{Au}$ SC. Thus, we have shown that for the coefficient of quantum efficiency $Q(\lambda)$ of the CdS/CdTe/ITO heterosystem to be enhanced, it is necessary to reduce the negative influence of the developed grain-boundary surface of the base layer on the processes of diffusion and distribution of nonequilibrium current carriers generated in near $\mathrm{CdS} / \mathrm{CdTe}$ interface under the action of photons from the short-wave range of the visible spectrum.

If the glass $/ \mathrm{SnO}_{\mathrm{x}}: \mathrm{F} / \mathrm{CdS} / \mathrm{CdTe} / \mathrm{ITO} \mathrm{SC}$ was illuminated from the frontal side and the applied bias was positive, the growth of voltage resulted in a reduction of the $Q(\lambda)$ values in the whole spectral range of photosensitivity (Fig. 2).

In this case, the amplitude of reduction increased as the photon wavelength grew from 650 to $820 \mathrm{~nm}$. An increase of the direct bias resulted in a reduction of the electric field in the spacecharge region (SCR) of a frontal heterojunction. This stimulated the rise of the recombination losses of non-equilibrium current carriers in the SCR. The growth of the direct bias also resulted in a narrowing of the SCR, which caused an increase of the recombination losses of the generated current carriers in the bulk when the radiation wavelength increased. When the measurements of the $\mathrm{CdS} / \mathrm{CdTe} / \mathrm{ITO} \mathrm{SC}$ at $U>0.8 \mathrm{~V}$ were carried out, a change of the photocurrent polarity from positive to negative was registered.

The change of the photocurrent polarity was caused by the existence of two heterojunctions in the $\mathrm{CdS} / \mathrm{CdTe} / \mathrm{ITO}$ heterosystem, which were in the opposite connection [1] namely, the $n$ $\mathrm{CdS} / p$-CdTe and $p^{+} \mathrm{CdTe} / n^{+}$ITO ones. The electrical resistance of the $n$-CdS $/ p$-CdTe heterojunction decreased as the direct bias grew, so that the greater part of the voltage began to drop across the $p^{+} \mathrm{CdTe} / n^{+} \mathrm{ITO}$ heterojunction, for which such polarity of the voltage caused the reverse bias. As a result, the SCR dimensions of the $p^{+} \mathrm{CdTe} / n^{+} \mathrm{ITO}$ heterojunction started to grow, which led to an 
effective redistribution of equilibrium current carriers by this potential barrier. In so doing, most effectively were distributed those current carriers which were generated near the SCR of the $p^{+} \mathrm{CdTe} / n^{+} \mathrm{ITO}$ heterojunction when the $\mathrm{SC}$ was illuminated from its back side with photons from the long-wave range of the spectrum.

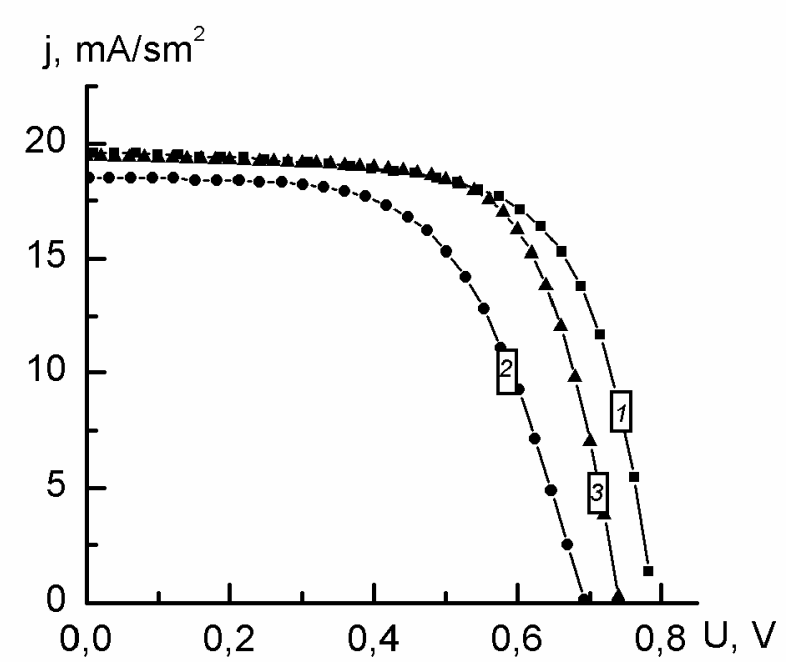

Fig. 3. Light I-V characteristics of $\mathrm{SC}$ glass $/ \mathrm{SnO}_{\mathrm{x}}: \mathrm{F} / \mathrm{CdS} / \mathrm{CdTe} / \mathrm{Cu} / \mathrm{Au}$ (curve 1), $\mathrm{SC}$ glass $/ \mathrm{SnO}_{\mathrm{x}}: \mathrm{F} / \mathrm{CdS} / \mathrm{CdTe} / \mathrm{ITO}$ (curve 2) and $\mathrm{SC}$ glass $/ \mathrm{SnO}_{\mathrm{x}}: \mathrm{F} / \mathrm{CdS} / \mathrm{CdTe} / \mathrm{Cu} / \mathrm{ITO}$ (curve 3 )

The investigation of quantum efficiency allows assuming that the $\mathrm{Cu} / \mathrm{ITO}$ back contact is optimum for use. The light I-V characteristics of $\mathrm{SC}$ with $\mathrm{Cu} / \mathrm{Au}$ back contact, ITO back contact and $\mathrm{Cu} / \mathrm{ITO}$ back contact are presented in Fig. 3 . The $\mathrm{SC}$ with $\mathrm{Cu} / \mathrm{Au}$ back contact has efficiency $10.4 \%$ with $U_{\mathrm{oc}}=790 \mathrm{mV}, J_{\mathrm{sc}}=20.1 \mathrm{~mA} / \mathrm{cm}^{2}$ and $F F=0.66$. On conditions that the front side is illuminated the efficiency of SC with ITO back contact is $7.7 \%$ with $U_{\mathrm{oc}}=690 \mathrm{mV}$, $J_{\mathrm{sc}}=18.5 \mathrm{~mA} / \mathrm{cm}^{2}$ and $F F=0.60$. The efficiency of $\mathrm{SC}$ glass $/ \mathrm{SnO}_{\mathrm{x}}: \mathrm{F} / \mathrm{CdS} / \mathrm{CdTe} / \mathrm{Cu} / \mathrm{ITO}$ is $9.9 \%$ with $U_{\mathrm{oc}}=740 \mathrm{mV}, \quad J_{\mathrm{sc}}=19.5 \mathrm{~mA} / \mathrm{cm}^{2} \quad$ and $F F=0.68$. The efficiency of this SC increases to $10.3 \%$ during the first six month of service and remains higher then $10 \%$ after six years service. It has been established by analytical processing of the light I-V characteristics that the use of the copper nanolayers in the design of transparent contact led to the decreasing of reverse current density saturation. It was shown, that as against SC with $\mathrm{Cu} / \mathrm{Au}$ back contact the $\mathrm{SC}$ with $\mathrm{ITO} / \mathrm{Cu}$ back contact would have the same high stability as well as SC with ITO back contact.

\section{Summary}

New design of a transparent back electrode based on composition $\mathrm{Cu} / \mathrm{ITO}$ is proposed. As a result of comparative researches of film solar cells glass/SnO $: \mathrm{F} / \mathrm{CdS} / \mathrm{CdTe} / \mathrm{ITO}$, glass $/ \mathrm{SnO}_{\mathrm{x}}: \mathrm{F} / \mathrm{CdS} / \mathrm{CdTe} / \mathrm{Cu} / \mathrm{ITO}$ and glass $/ \mathrm{SnO}_{\mathrm{x}}: \mathrm{F} / \mathrm{CdS} / \mathrm{CdTe} / \mathrm{Cu} / \mathrm{Au}$ it has been shown that the using of $\mathrm{Cu}$ nanolayer before the deposition of transparent film ITO contact allows receiving the stable bifacial solar cells with efficiency more than $10 \%$, which can be used in the design of tandem thin film solar cells.

\section{Acknowledgments}

The work was supported by STCU under Project 4301. We thank Doctor D.L. Batzner, for his help with measurements of the electrical characteristics of the solar cells.

\section{References}

[1] Bube R.H. Properties of Semiconductor Materials. Photovoltaic Materials-(London: Imperial College Press, Vol.1. 1999.)

[2] M. Wimbor, A. Romeo, and M. Igalson, Optoelectron. Rev. 8, 375 (2000).

[3] B. L. Sharma and R. L. Purohit, Semiconductor Heterojunctions (Pergamon, Oxford, 1974; Radio i Svyaz', Moscow, 1979).

[4] A. Niemegeers and M. Burgelman, J. Appl. Phys. 81, 2881 (1997)

[5] D. L. Batzner, A. Romeo, H. Zogg, et al., Thin Solid Films 381, 151 (2001).

[6] Bonnet D., Meyers P. // J. Mater. Res, 13, N10,2740 (1999). 